Review Article

\title{
Beyond retrovirus infection: HIV meets gene therapy
}

\author{
Flávia Helena da Silva, Tiago Pires Dalberto and Nance Beyer Nardi \\ Universidade Federal do Rio Grande do Sul, Departamento de Genética, Laboratório de Imunogenética, \\ Porto Alegre, RS, Brazil.
}

\begin{abstract}
The human immunodeficiency virus (HIV) is classified as a retrovirus because of its RNA genome and the fact that it requires reverse transcriptase to convert it into DNA. This virus belongs to the lentivirinae subfamily and is able to infect quiescent cells but is better known for its association with acquired immunodeficiency syndrome (AIDS) and can be described as one of the most effective vectors for gene transfer. Biosafety concerns are present whenever viral vectors are employed but are particularly pertinent to the development of HIV-based vectors. Insertional mutagenesis and the production of new replication-competent viruses $(\mathrm{RCV})$ have been pointed to as major problems, but experimental data have shown that safe protocols can be developed for their production and application. Virological, evolutionary, immunological and cell biology studies must be conducted jointly to allow the clinical use of HIV vectors. This review will focus on the general properties, production and applications of retrovectors in gene therapy, with particular emphasis on those based on HIV systems.
\end{abstract}

Key words: HIV, MLV, retrovirus, lentivirus, gene therapy.

Received: February 15, 2005; Accepted: August 26, 2005.

\section{Introduction}

The basic principle of gene therapy is the introduction of exogenous genetic material to correct or modify the cell functions. The development of methods for the delivery of therapeutic genes to specific target cells has been under intense investigation for the last decade (reviewed in Romano et al., 2000; Amalfitano and Parks, 2002). Although the identification of the appropriate therapeutic gene as well as the target cell are essential for successful gene therapy, identifying the most suitable gene transfer method for a determined group of target cells is also of fundamental importance.

The vectors used to transfer genes are basically classified as viral or non-viral, each presenting its own benefits and drawbacks. Retroviruses are largely used as stable gene transfer systems (reviewed in Chu et al., 1998), and among them lentiviruses have been increasingly used due to their greater ability to transduce quiescent cells. This review will focus on the general properties, production and applications of retrovectors, with emphasis on HIVbased vectors.

Send correspondence to Nance Beyer Nardi. Universidade Federal do Rio Grande do Sul, Departamento de Genética, Laboratório de Imunogenética, Av. Bento Gonçalves 9500, 91501-970 Porto Alegre, RS, Brazil. E-mail: nardi@ufrgs.br.

\section{General Properties of Retroviruses}

All members of the family Retroviridae (oncovirus, lentivirus and spumavirus) present a RNA genome which is retro-transcribed into DNA by the enzyme reverse transcriptase. When this process is concluded (if all the proteins, cellular and viral factors required for reverse transcription are present) the provirus is able to integrate into the genome of the host cell. This is possible because regulatory signals are present in terminal regions of the provirus genome, named long terminal repeats (LTRs) (Figure 1). The viral genome also presents enhancers and other elements that regulate the expression of viral genes. Such enhancers can be localized within LTRs and other regulatory fuctions can be provided by accessory and regulatory genes such as tat and rev as well as vif, vpr, vpu and nef. The tat gene is a transactivator of the 5' LTR that acts as a viral promoter while the Rev protein is necessary to transport the viral transcripts from the nucleus to the cytoplasm mediated by the rev responsive element (RRE). Other accessory genes can be related to virulence and immune system gene modulation (Lanciotti, 2001).

In the genome of all retroviruses there are at least three open reading frames (ORFs) each of which encodes for a different viral element, e.g. the capsid and matrix ( $g a g$ gene), enzymes ( $p o l$ gene) and envelope (env gene) 
(Figure 1). The capsid encases the genome and protects the viral genetic material, while enzymes are needed for viral replication and integration of the provirus and the envelope consists of glycoproteins that recognize specific cell receptors and determine the tropism of infection. Members of the Lentivirinae subfamily present a more complex genome than members of the Oncovirinae subfamily because the former contain additional regulatory and accessory genes (Swanstrom and Wills, 1997).

Integration of the viral genome into the host genome depends on its ability to enter the cell nucleus. In oncoviruses this is only possible when the nuclear membrane disintegrates during cell division but lentiviruses have an active

\begin{tabular}{|l|l|l|l|}
\hline LTR gag & pol & env & LTR \\
\hline $\begin{array}{l}\text { Encapsidation } \\
\text { signal } \Psi\end{array}$
\end{tabular}

Figure 1 - Genomic organization of a typical retrovirus genome. Additional genes are present in lentiviruses such as HIV. transport mechanism which allows the provirus to enter the nucleus through the pores in the nuclear membrane (Bukrinsky et al., 1992). The active transport of lentivirus provirus is in part mediated by nuclear localization sequences (NLS) and the formation of proteic transportation complexes dependent on accessory genes such as HIV $v p r$ (Naldini et al., 1996a and b; Vodicka et al., 1998) or on mechanisms regulating retrotranscription, such as strand displacement (resulting from the synthesis of double strand DNA from viral RNA) present in the pre-integration complex (PIC) (Klarmann et al., 2003) (Figure 2). These are very important features in the context of gene therapy because such properties mean that HIV can be used in a different group of target cells in comparison to MLV-based vectors. For example, to transduce human hematopoietic progenitors in the absence of cytokine stimulation it may be better to use HIV-based vectors than murine leukemia virus (MLV) vectors (Salmon et al., 2000).

The most famous lentivirus is the human immunodeficiency virus (HIV) which is historically related to the ac-

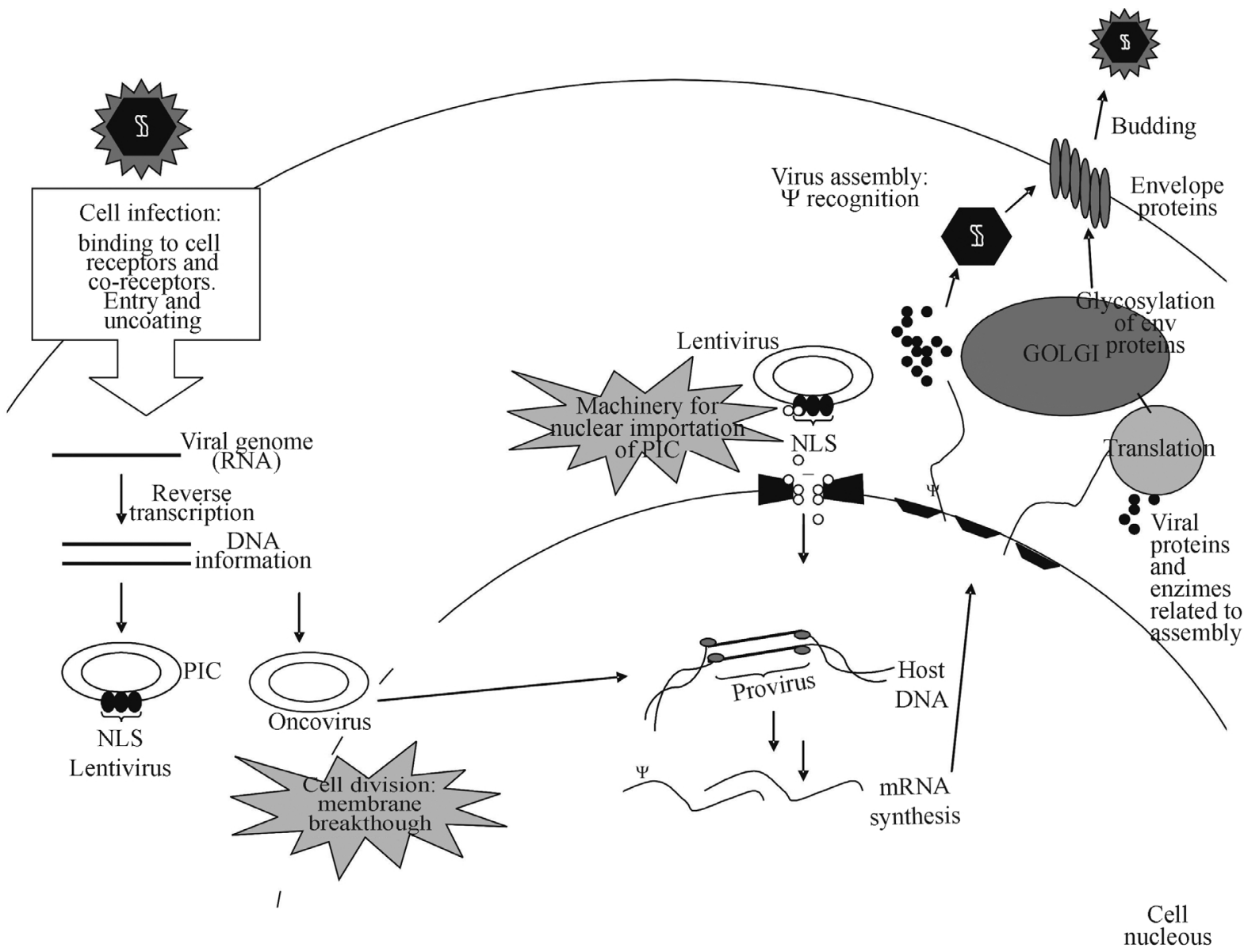

Figure 2 - Schematic diagram of cell infection by retrovirus. Infection starts by binding to cell receptors, which leads to virus entry and uncoating. Retrotranscription occurs in the cytoplasm. Lentiviruses have a nuclear localization signal (NLS) in their preintegration complex (PIC) that interacts with an active nuclear importation machinery dependent on viral and host factors. Oncoviruses do not present this system, and thus depend on membrane breakthrough to access the nucleus. In the nucleus, proviruses will integrate into the host DNA genome. Viral assembly occurs in the cytoplasm, and viruses are liberated from the infected cell by budding. 
quired immune deficiency syndrome (AIDS) pandemic and still poorly understood despite the large body of knowledge resulting from intense research over the last twenty years (reviewed in Lever et al., 2004). HIV preferentially infects cells possessing the CD4 surface marker, such as macrophages and helper $\mathrm{T}$ lymphocytes, although it may also bind to the CCR5 and CXCR4 co-receptors (Holmes et al., 2001). In order to expand the possible applications of HIV vectors in gene therapy, it is necessary to use different envelope constructions that may enable the infection of different target cells. This process, called pseudotyping (Burns et al., 1993), was initially designed for vectors based on MLV (Yee et al., 1994) but has now been applied to several other viral vectors and has allowed the manipulation and concentration of viral stocks.

\section{Production of Retrovectors}

The construction of viral vectors implies the removal of some of the genes present in the wild type virus, since the vectors should be able to infect cells, retrotranscribe, integrate its genome into the host DNA and express the therapeutic gene without causing any disease. Specific genes and sequences related to virulence or unnecessary to transgene expression must be deleted and interesting genes may fill the available space. These minimal helper-packaging elements (or constructs) are the basis for the genetic engineering of virus-based vectors and the procedure itself is called transient transfection (Pear et al., 1993). Transient transfection relies on the independent delivery of such constructs, each expressing a few primary elements for the assembly of viable viral particles (structural and envelope genes, for example). The construct that represents the encapsidated genome is the therapeutic vector, containing all the sequences required for the expression of the transgene in the target cells (reviewed in Delenda, 2004).The use of separated constructs is said to reduce the formation of helper-virus (replication-competent viruses or RCV) because more recombinational events would be necessary to restore the wild-type phenotype. (Soneoka et al., 1995) (Figure 3).

The industrial scale-up production of viral vectors through transient transfection is still an issue, since this procedure is not as homogenous as it should be. The titers achieved are somewhat variable and the concentration of viral stocks is still to be standardized (Pagès and Bru, 2004). These limitations explain why there is a great effort from the scientific community towards the improvement of viral vector production in a standardized manner, possibly mediated by stable packaging cell lines (PCLs). Table 1 presents examples showing that transiently transfected cells may lead to stable PCLs if cell clones that stably produce viral vectors are selected.

Stable PCLs constitutively express some of the chosen genes which may be subjected to the regulation of inducible systems. To activate virus production, the inductor

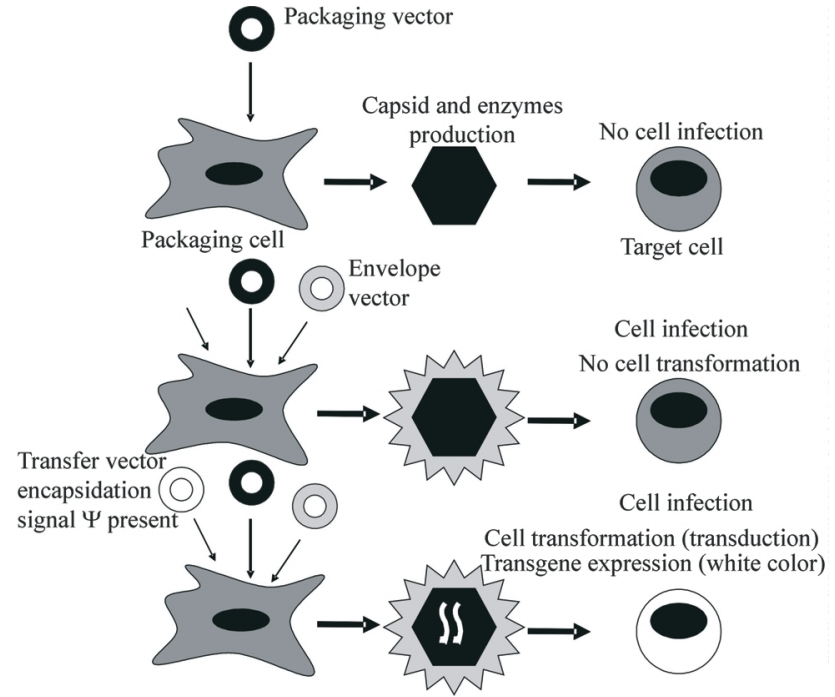

Figure 3 - Production of retrovectors by transient transfection (adapted from Silva, 2002). Packaging cell lines are transiently transfected with the vectors responsible for the assembly of recombinant viruses. In cases (A) and (B), retrovectors are not functional. Complete vectors able to infect and transduce target cells are produced only when the packaging cells are transfected with the three plasmids (C).

element must be present in the cultures, as is the case of the tetracycline-induced systems described by Chen et al. (1996), Farson et al. (2001) and Xu et al. (2001). Since PCLs can be previously characterized and tested for RCV production, the production of viral vector becomes safer when stable transfection is combined with regulated expression systems. If the titers achieved are not high enough, or if RCV is detected, the PCL can be eliminated and another stable clone tested. This is a time-consuming method but worth performing since yield and quality may differ widely among stable and non-stable PCLs (Corbeau et al., 1996; Klages et al., 2000). Comparative studies involving vectors produced on a large scale are important in validating these arguments, particularly if the transfection methods can be compared in the same cell lineage.

Cell lines present different susceptibility to transfection (reviewed by Pagès and Bru, 2004). The most frequently used PCL is currently 293, but other cell types are being investigated. We have recently developed an interesting alternative PCL for the production of HIV-based vectors (Silva et al, unpublished results) using a murine mesenchymal stem cell line previously established in our laboratory (Meirelles and Nardi, 2003).

The approval of a retroviral PCL, whether transient or stable, depends also on the pattern of insertional mutagenesis presented by the viruses produced and potential recombination with human endogenous retroviral sequences or wild type viruses (Cornetta et al., 1991). These concerns are increased when the wild type virus involved is related to a human severe pathology such as AIDS but the reduction of overlapping sequences between therapeutic vectors and packaging components has been proved to reduce RCV for- 
Table 1 - Characteristics of some of the protocols available for retrovector production.

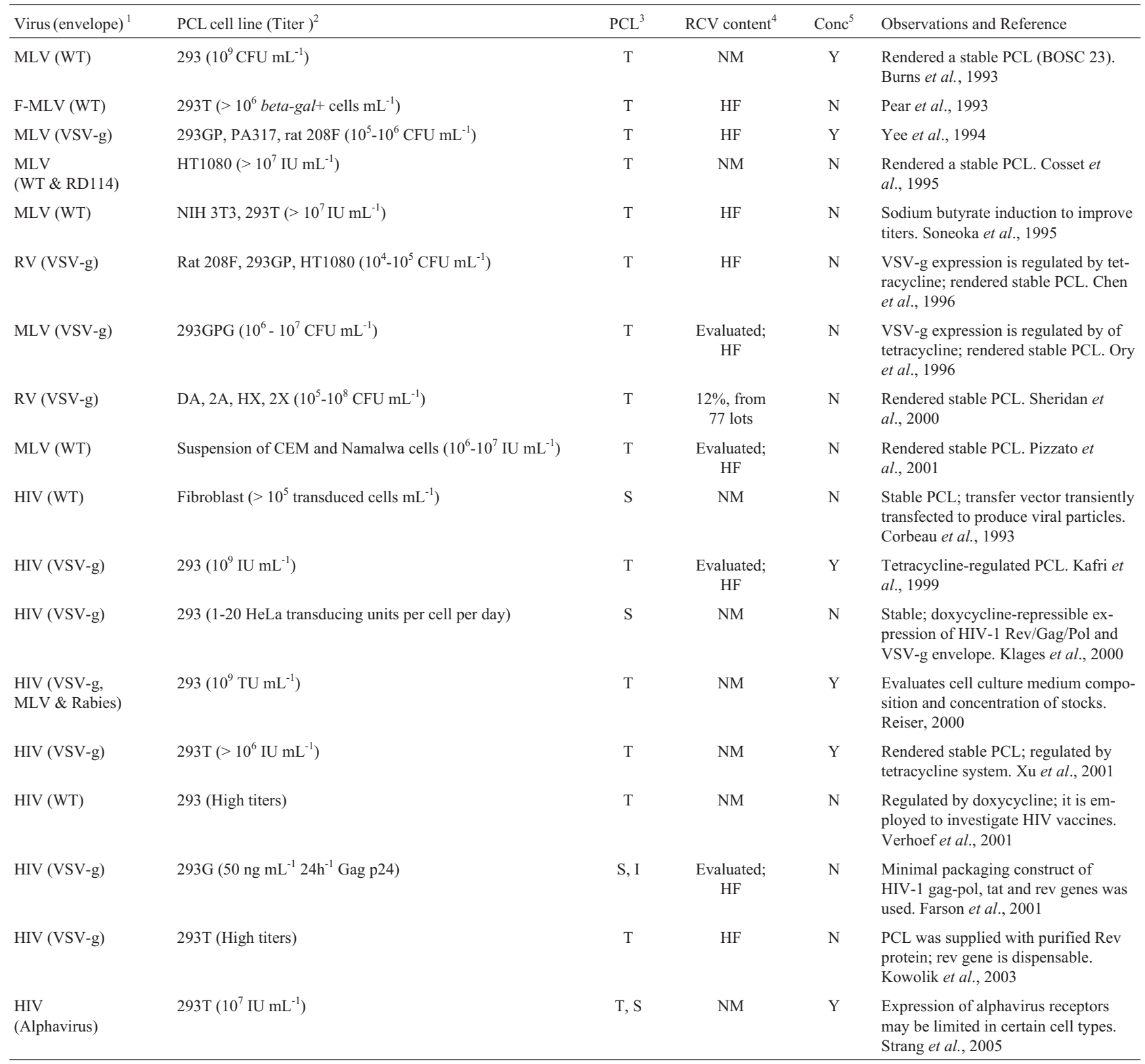

${ }^{1} \mathrm{MLV}=$ murine leukemia virus; $\mathrm{RV}=$ retrovirus; $\mathrm{HIV}=$ human immunodeficiency virus; $\mathrm{VSV}=$ vesicular stomatitis virus; $\mathrm{WT}=$ wild type. ${ }^{2} \mathrm{PCL}=$ packaging cell line; $\mathrm{CFU}=$ colony-forming units; $\mathrm{IU}=$ infection units; $\mathrm{PFU}=$ plaque-forming units; $\mathrm{TU}=$ transducing units; pgGagp $24=$ picograms of Gag p24 protein. ${ }^{3} \mathrm{I}=$ inducible; $\mathrm{S}=$ stable; $\mathrm{T}=$ Transient. ${ }^{4} \mathrm{RCV}=$ replication-competent viruses: $\mathrm{HF}=$ Helper-free; $\mathrm{NM}=$ Not mentioned. ${ }^{5}$ Conc $=$ concentrated stocks available: $\mathrm{Y}=$ yes; $\mathrm{N}=$ no.

mation and may be helpful in overcoming these problems (Otto et al., 1994; Sheridan et al., 2000). These aspects of vector production need to be properly measured, but as shown in Table 1 there are different ways of quantifying viruses and detecting RCVs. Padronization is also needed to compare the results from different research groups.

The first clinical-grade HIV lentiviral vector has already been tested in gene therapy for transgene ex vivo delivery, but still needs to be evaluated in a phase three clinical trial confronting a greater number of individuals (Manilla et al., 2005). Three clinical protocols are being developed to evaluate the application of this specific HIV construct in anti-AIDS therapy, through different approaches (Gene Therapy Clinical Protocols Worldwide, 2005). These trials are a hallmark in the establishment of lentivector gene transfer protocols, and may be helpful in consolidating HIV vectors as safe and efficient tools for clinical cell transduction

Because recombination events between therapeutic vectors and endogenous retroviral sequences have been reported (Chong et al., 1998) the development of sensitive assays to specifically detect recombinant lentiviral DNA mobilization would be of great value for clinical application(Wu et al., 2000; Sastry et al., 2003). Contamination of 
vector supernatants with packaging cell line DNA can also be a source of false positive results in tests for RCV detection if no functional tests are simultaneously done (Chen et $a l ., 2001)$. These techniques can also help to standardize virus production, not only providing a reproducible method for viral titration (Sastry et al., 2002) but also improving safety tests. It is expected that new assays for the determination of safety level will lead to the improvement of viral vectors, particularly HIV-based vectors. Recently, a specific methodology was described to evaluate the RCV content in HIV vectors produced on a large scale (Escarpe et al., 2003).

\section{Features of the HIV Virus}

The development of HIV vectors for anti-HIV gene therapy is the most logical application of this system, but the ability of HIV to specifically target CD4+ non-cycling cells makes it a promising candidate for many other situations in which in vivo gene delivery is important (Poeschla et al., 1996). In fact, this possibility has led to experimental evidence for its application in the transduction of a wide variety of cell types, such as hematopoietic progenitor and stem cells (Reiser et al., 1996; Case et al., 1999), postmitotic neurons (Naldini et al., 1996a; Reiser et al., 1996), fibroblasts and human primary macrophages (Naldini et $a l ., 1996 \mathrm{~b})$, and primary human marrow stroma (Bahner et al., 1997).

To produce viral vectors it is possible to employ first, second and third generation systems based on the number of plasmids to be transfected to the PCL (Figure 4). First generation vectors present only two plasmids, so that two combinations are possible: envelope and packaging vector or packaging with intact envelope sequence and the therapeutic vector. In terms of HIV vectors, two-plasmid systems have been described in the past, but few reports present env deletion in the structural vector (Page et al., 1990; Landau et al., 1991; Reiser et al., 1996).
A three-plasmid system, which includes one therapeutic vector, one structural vector without the wild type HIV env gene and one additional VSV-G envelope vector, was described by Naldini et al. (1996a) as an efficient system to achieve gene transfer to the central nervous system a logical application if we consider that neurons are quiescent or poor mitotic cells and that HIV is a lentivector. Blömer et al. (1997) employed this HIV-based system in the murine central nervous during a comparative study including oncoviral (based on MLV), adenoviral and adenoassociated viral systems but only the lentiviral vector was able to efficiently and stably infect quiescent cells, allowing b-galactosidase transgene expression for over six months. Mordelet et al. (2002) were able to modify the protocol used by Blömer et al. (1997) to reinforce the efficiency of HIV-based vectors in transferring genes to the central nervous system. It is important to state, however, that adeno-associated viral vectors can also infect this tissue, so the transduction efficiency (but not long term stable transgene expression) of these two types of viral vector may be similar.

Second generation vectors include three plasmid systems, which have been important in the design of safer HIV vectors because they are less prone to interplasmid recombination leading to restoration of the wild-type phenotype and also do not transfer packaging and wild-type envelope sequences to target cells.

Third generation vectors are now considered the safest HIV vectors available. These vectors are produced from four different plasmids, i.e. therapeutic vector, envelope vector, packaging vector (containing gag, pol and the responsive element of rev gene) and the rev vector (Dull et al., 1998). The presence of tat in packaging vectors is a controversial issue because it is not interesting that the 5, LTR of HIV-based vectors is transactivated by tat, since interference of the LTR promoter with the internal promoter may reduce the level of expression of the transgene (Cui et al., 1999; Zaiss et al., 2002). Rev gene, however, is consid-

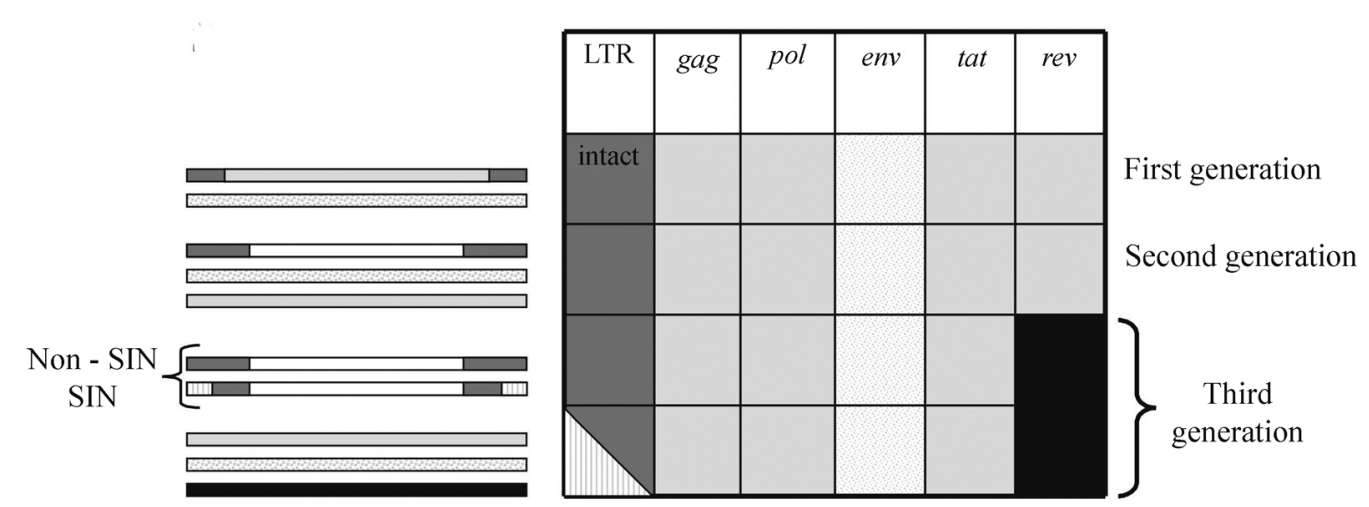

Figure 4 - Schematic diagram of first, second and third generation vectors. Long terminal repeats (LTR, dark gray), structural and accessory genes from packaging constructs (gray) and envelope construct (light gray). Self-inactivating (SIN) vectors are represented by altering the LTR shade (gray and light gray). First generation vectors are derived from only two constructs (transfer and envelope). Second generation vectors present three constructs (transfer, packaging and envelope). Third generation vectors present the rev gene in a different construct (black) with a total of four plasmids: transfer (SIN or non-SIN), packaging (gag, pol and tat genes only), rev and envelope vectors. 
ered necessary for the production of high titers and higher transduction efficiency, when appropriate rev responsive elements are present (Parolin et al., 1994).

Another important feature of retroviral vectors that has contributed positively to the design of HIV-based vectors is the development of self-inactivating (SIN) vectors (Figure 5), characterized by one-way infection of target cells - an important advance for safer retroviral gene therapy protocols. Deletions of specific regions of viral LTR can impair the replication potential of a virus without altering gene transfer efficiency (Miyoshi et al., 1998).

Long terminal repeats are very important for virus integration and replication and are composed of three parts (U3, R and U5), the LTR only being complete at the provirus level. The U3 region is partial or totally deleted at the 3' LTR and after reverse transcription this deletion can be transferred to the 5' LTR of the provirus maintaining the integration of regulatory signals but impairing the ability of the provirus to replicate so that the LTR is transcriptionally inactive in the provirus (Miyoshi et al., 1998; Zufferey et al., 1998; Iwakuma et al., 1999). However, Logan et al. (2004) recently reported integrated self-inactivating lentiviral vectors capable of producing full-length genomic transcripts competent for encapsidation and integration, showing that refined molecular studies are needed to assess the safety of SIN HIV vectors.

If the 5' U3 is also deleted, the space left can be used to clone a heterologous promoter, resulting in the provirus being a SIN vector without LTR promoter activity. This molecular alteration results in a tat-independent transcriptional mechanism, so the viral promoter does not interfere with the heterologous promoter and the possibility of activation of cellular genes flanking the vector integration site is reduced (Yam et al., 2002).

Regardless of which U3 is altered, SIN and non-SIN vectors are capable of integrating the provirus into the host genome, although this may result in insertional mutagenesis (Cornetta et al., 1991). The first clinical protocol was performed with infusion of autologous T-lymphocytes ex-

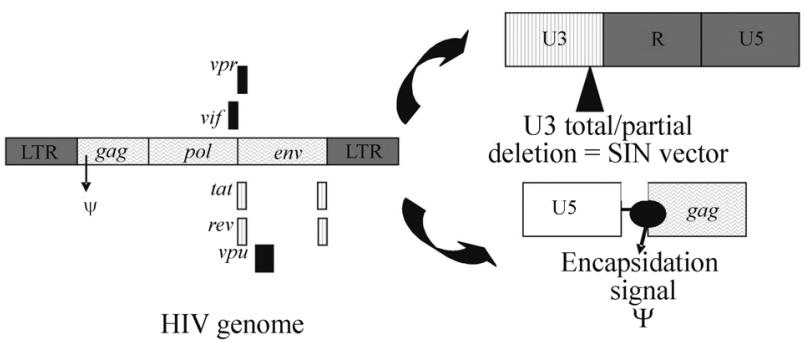

Figure 5 - Alterations of the HIV genome. Genes such as $v p r$, vif and vpu that are deleted from the transfer vector (black). Structural genes such as gag, pol and env (light gray). Long terminal repeat composed of the U3, R and U5 segments (gray). When the U3 segment is partially or almost completely deleted a self inactivating (SIN) vector is formed. Besides U3 modification, it is important to maintain the encapsidation signal psi in the transfer vector. Because the psi signal presents an overlapping of sequences with gag gene, gag deletions must be carefully analyzed. panded and transduced in vitro by a MLV vector with the normal adenosine deaminase gene (Blaese et al., 1995; Bordignon et al., 1995). The follow-up study involved two years of treatment and two years of assessment, after which the retroviral gene therapy protocol was considered successful despite the need for simultaneous exogenous enzyme replacement therapy (Blaese et al., 1995).

Cavazzana-Calvo et al. (2000) proposed a retroviral gene therapy protocol to deliver a copy of normal $\gamma \mathrm{c}$ cytokine receptor subunit of interleukine-2,-4, -7, -9 and -15 receptors to correct X-linked human severe combined immunodeficiency (SCID-X1). As the adenosine deaminase protocol, target cells (CD34+ cells) were transduced in vitro and reinfused into the patients. However Hacein-BeyAbina et al. (2003) reported that two of the treated patients presented pre-malignant cell proliferation as a consequence of MLV vector integration close to the LMO2 gene promoter (a proto-oncogene). These findings had a negative impact on viral gene therapy (Check, 2002a and b), the same having happened after the death of Jesse Gelsinger in 1999 due to gene therapy treatment (Belgian Biosafety Server, 2005). The risks of developing long-term cancer because of insertional mutagenesis associated with retroviral vectors is still an issue to be solved, but some findings have helped to estimate the risks for onco and lentivectors.

The pattern of retroviral integration has always been considered variable and random, but recent reports described some level of preference in terms of integration hotspots. Very interestingly, these reports are different for HIV and MLV, because the former integrates into active genes while the latter preferentially integrates into transcription start regions (Schröder et al., 2002; Wu et al., 2003). This agrees with the findings of Hacein-Bey-Abina et al. (2003) for LMO2 gene activation due to integration of MLV near the LMO2 proto-oncogene promoter. These results indicate that besides having different integration patterns, vectors based on these viruses could present different theoretical risks for insertional mutagenesis.

It is true, however, that these important studies have been done with wild type HIV and MLV viruses and so far no similar study has been conducted with the recombinant pseudo-typed viruses commonly used in retroviral gene therapy, although the SCID-X1 case cited above supports the conclusions of Schröder et al.(2002) and Wu et al. (2003). It is important to remember that HIV may be less prone to insertional mutagenesis than MLV, but how the observations discussed above can be transposed to viral vectors still needs to be properly evaluated. For instance, in a murine model of $\beta$-thalassemia the frequency of proviral integration within genes regulating hematopoiesis has been considered to be too high (Imren et al., 2004), but if these integrations are far from the transcriptional start sites the risk of transcribing flanking genes can be considered small (Wu et al., 2003). 
A comparative study of HIV and MLV vectors has reported different implications for vector safety, since MLV vectors presented higher readthrough frequencies for the 3 ' polyadenylation signal than HIV vectors. Interestingly, a SIN HIV vector presented results similar to the MLV vector, suggesting that SIN HIV and MLV vectors may present similar risks of activation of flanking genes if no modifications are made in the 3 ' poly(A) signals, such as changing the wild-type poly(A) signal for a stronger one (Zaiss et al., 2002). Studies like these are very important in helping to define boundaries between retrovectors and to properly evaluate the safety of such constructs.

Even though these data represent the first results towards the development of safer retroviral vectors - particularly HIV vectors - for the future in vivo use of lentiviral gene therapy, some modifications have been proposed in order to improve even more the HIV-based system. Many suggestions have been made based on knowledge of HIV biology acquired from different fields, including molecular virology, cell biology, immunology, etc. Almost all structural, accessory and regulatory HIV genes have been tested for possible advantages in gene therapy vectors and the minimal requirements for the construction of HIV-based vectors has started to be defined (Zufferey et al., 1997; Sutton et al., 1998; Wu et al., 2000).

A minimal HIV-based vector has been developed presenting a lower number of viral sequences (Kim et al., 1998) and which may represent a safer construct since the probability of recombination with wild-type viruses or endogenous retroviral sequences is diminished (Miyoshi et al., 1998; Iwacuma et al., 1999). The number of known cis regulatory elements is still increasing, allowing the improvement of SIN vectors (Déglon et al., 2000; Ismail et al., 2000; Ramezani et al., 2000; Yam et al., 2002). Sequential deletions of regulatory regions of the HIV genome have been tested and it was found that some elements were essential for efficient gene transfer (Parolin et al., 1994; Hildinger et al., 1999; Sirven et al 2000; Manganini et al., 2002) but, in contrast to previous results, some were unnecessary (Cui et al., 1999). Corroboration of such observations in vivo has also been reported (Baekelandt et al., 2002). The major aspects of these elements are reviewed below.

The promoter chosen to drive the expression of the transgene is probably the first element that should match the target cells. In a comparative study Bonamino et al. (2004) evaluated CMV, EF1alfa and PGK promoters for their ability to transfer the CD40L gene to human B-cell precursors of acute lymphoblastic leukemia via secondgeneration SIN HIV vectors, the best transcription efficiency being achieved with the CMV promoter. However, Yam et al. (2002) reported that the CMV promoter showed low activity in CD34+, erythrocytic and myelomonocytic cells. In both cases, the promoter activity was constitutive and it seems that regulated lentiviral vectors better reflect physiological transgene expression levels (Mitta et al., 2004; Markusic et al., 2005). Despite these observations, the molecular context in which these promoters were evaluated is of major importance because cis elements can have synergistic effects on cell transduction efficiency.

Special splicing signals, constitutive RNA transport elements and woodchuck hepatitis virus post-transcriptional regulatory elements (WPRE) have all been used to achieve effective expression of protein-coding transgenes (Schambach et al., 2000). In contrast to what was previously thought (Gasmi et al., 1999), WPRE elements can improve the stability of mRNA and RNA processing (Kraunus et al., 2004) and when used in combination with other elements (e.g. such as spleen focus-forming virus promoter (SFFV) and HIV central flap) results in significantly higher transduction rates (Yam et al., 2002; Demaison et al., 2002).

The nuclear import of HIV pre-integration complex (PIC) depends on a strand displacement (called the central DNA flap) generated during reverse transcription (Stevenson, 2000) which is recognized by viral and host elements, suggesting that the nuclear importation of PIC depends on both viral and host elements (Bukrinsky et al., 1992; Gallay et al., 1997). Contrary to previous reports (Dvorin et al., 2002), it is now known that the HIV central flap improves transduction efficiency because of an increase in PIC nuclear translocation of HIV vectors (Van Maele et al., 2003). For hepatocyte transduction, rates were higher when the central flap was present (Park and Kay, 2001; VandenDriessche et al., 2002), the same being true for the transduction of human nondiving monocytes and T-lymphocytes (Manganini et al., 2002).

Multi-expression HIV-based vectors have been reported as versatile vectors based on their ability to express multiple transgenes (Reiser et al., 2000). Differential splicing and translational control depending on an internal ribosomal entry site (IRES) sequence did not decrease virus titers or the ability of virions to infect quiescent cells (Zhu et al., 2001), and these vectors may be used to deliver a reporter gene plus a therapeutic gene or two therapeutic genes at the same time.

\section{Applications of HIV-Based Vectors}

The ability of lentivectors to infect nondiving cells has been shown in various target cells, such as primary cultures from different tissues and human progenitor cells. More specifically, the efficiency of HIV vectors has been shown in targets such as hematopoietic stem cells (HSC) (Akkina et al., 1996; Case et al., 1999; Miyoshi et al., 1999; An et al., 2000; Demaison et al., 2002) and peripheralblood monocyte-derived dendritic cells (Chinnasamy et al., 2000). The best results concerning the HSC transduction have been obtained using HIV-vectors instead of MLVvectors (Case et al., 1999; An et al., 2000). Other lentiviruses, such as the feline immunodeficiency virus (FIV), 
have been shown to be unsuitable for delivering genes to this type of progenitor cell (Price et al., 2002). Specific modifications of HIV-based vectors resulting in better transduction rates of CD34+-derived hematopoietic cells have already been reported (Sirven et al., 2001).

Promising results have been found for the in vivo transduction of airway epithelia (Johnson et al., 2000), as well as in situ application of HIV vectors in human and mice corneal tissue, showing that HIV-based vectors may be a promising tool for gene therapy of recessive forms of inherited retinal degradation (Takahashi et al., 1999; Wang et al., 2000; Bainbridge et al., 2001; Kostic et al., 2003). Absence of toxic effects or immune responses after the in vivo administration of HIV vectors have been reported (Miyoshi et al., 1998; Naldini, 1998; Han et al., 1999; Pan et al., 2002) and recent experiments with heart grafts in mice support these findings (Kearns-Jonker et al., 2004), showing that HIV vectors may present advantages other than the ability to infect quiescent cells.

In fact, the remarkable efficacy of HIV-based vectors for globin gene transfer observed in Cooley anemia shows other potential uses of this tool (Rivella et al., 2003), which is also employed in studies concerning the gain of function of certain genes in early human development processes through the transduction of human embryonic stem cells (Ma et al., 2003). Zhang et al. (2002) reported the transduction of mesenchymal stem cells (MSC) with the maintenance of their differentiation status. Carlotti et al. (2004) showed that adipocytes can also be efficiently transduced with HIV-based vectors without showing any side effects, which was not the case when adeno-associated vectors were employed.

A comparison between adeno-associated and HIV vectors for the same application and for the same target cells is necessary, since it has not yet been defined if immune response is a common consequence of in vivo application of these vectors. For instance, Auricchio et al. (2001) found no differences in the efficiency of adeno-associated and HIV vectors for retina transduction and no immunological responses observed, contrasting with the report by Carlotti et al. (2004). On the other hand, immune responses following multiple administration of adeno-associated vectors have been reported (Kok et al., 2004), a problem that can be overcome through the use of novel AAV-serotypes (Louboutin et al., 2004). Vectors based on HIV have been employed as in vivo gene transfer system in Parkinson's disease (Déglon et al., 2000; Azzouz et al., 2002) and no immune responses have been detected, but in a gene therapy protocol for murine mucoploysaccharidosis type I, Di Domenico et al. (2005) observed that clearance of transduced cells by the immune system limited long-term treatment. It thus seems clear that despite the good results presented by HIV vectors so far more comparative studies are needed for AAV, MLV and HIV vectors. In a recent review Blesch (2004) compared in situ and in vivo protocols based on HIV and MLV vectors but no reviews comparing HIV and adeno-associated vectors are available.

In addition to their applications as therapeutic tools, HIV-based vectors can also be seen as a research tool. Due to the stability of HIV-mediated gene transfer it is possible to produce transgenic animals such as mice (Lois et al., 2002) and pigs (Hofmann et al., 2003), overcoming the microinjection problems which occur with superior mammals, such as primates.

Another promising application refers to the production of interference RNA (RNAi) inside target cells, RNAi being a very interesting alternative for silencing target genes, for basic research or for use in ablative gene therapy protocols (reviewed in Novina and Sharp, 2004). HIV-based systems have been shown to effectively silence genes in primary mammalian cells, stem cells and transgenic mice, representing cycling, non-cycling and differentiated cell progeny (Rubinson et al., 2003). Actually, some target cells may be refractory for transfection systems so viral vectors may be more appropriate for achieving higher transduction efficiency and long-term silencing (Mangeot et al., 2004).

In basic research, HIV-based vectors have been employed as RNAi delivery systems to knockout a specific gene and to evaluate its interaction with other genes (Sui et al., 2004; Yang et al., 2004). Scherr et al. (2005) used HIV vectors to investigate the potential therapeutic applications of RNAi as stable gene transfer systems for K562 cancer cell lines and for CD34+ cells from chronic myeloid leukemia patients and have shown that stable RNAi may represent an useful approach to cancer gene therapy. Not only HIV-based vectors have been evaluated in this context, with for instance, adeno-associated vectors having been used in intratumoral injection in order to promote antitumor response (Tsugawa et al., 2004). However, it seems more appropriate to employ a viral vector able to induce immune responses which constitute by themselves a therapeutic approach for cancer. Even so, adenovirus vectors have been tested for short interference RNA, since cancer cells may not be easy to transfect with non viral systems (Uchida et al., 2004). Which viral system to choose will depend on comparative studies. Wollmann et al. (2005) evaluated nine lytic viruses to transduce glioblastoma cells and observed that adeno-associated vectors were not as effective as vesicular stomatitis virus, murine minute virus and Sindbis alphavirus, although no lentiviruses were included in this study because members of this virus class do not present per se oncolytic potential.

\section{Final remarks}

In this review we have discussed some of the primary concerns involved in the use of HIV-based vectors as gene transfer tools. An open debate comparing the use of primate or non-primate lentivectors remains essential for the development of safety tests and the generation of more information about HIV vectors along with basic research on better 
and safer agents for clinical trials. In fact, researchers involved in retrovector design are beginning to address such questions using comparative studies and new approaches to evaluate issues such as immune responses and the side effects of retrovectors, all of which will enrich retroviralmediated gene therapy. In the near future we hope that phase three clinical trials will benefit from these discoveries and lead to biosafety protocols, particularly those related to the clinical use of HIV-based vectors.

\section{Acknowledgments}

We thank Guido Lenz, José Arthur Bogo Chies, Leonardo Karan Teixeira, Ricardo Dobrovolski, Andréia Vargas and Eduardo Avila for helpful discussions. This work was supported by grants from the Brazilian agencies Conselho Nacional de Desenvolvimento Cientifico e Tecnológico $(\mathrm{CNPq})$, Fundação de Amparo a Pesquisa do Estado do Rio Grande do Sul (FAPERGS) and Conselho de Aperfeiçoamento Pessoal em Nível Superior (CAPES).

\section{References}

Akkina R, Walton RM, Chen ML, Li Q-X, Planelles V and Chen ISY (1996) High-efficiency gene transfer into CD34+ cells with a human immunodeficiency virus type 1-based retroviral vector pseudotyped with vesicular stomatitis virus envelope glycoprotein G. J Virol 70:2581-2585.

Amalfitano A and Parks RJ (2002) Separating fact from fiction: Assessing the potential of modified adenovirus vectors for use in human gene therapy. Curr Gene Ther 2:111-133.

An DS, Wersto RP, Agricola BA, Metzger ME, Lu S, Amado RG, Chen ISY and Donahue RE (2000) Marking and gene expression by a lentivirus vector in transplanted human and nonhuman primate CD34+ cells. J Virol 74:1286-1295.

Auricchio A, Kobinger G, Anad V, Hildinger M, O'Connor E, Maguire AM, Wilson JM and Bennet J (2001) Exchange of surface proteins impacts on viral vector cellular specificity and transduction characteristics: The retina as a model. Hum Mol Genet 10:3075-3081.

Azzouz M, Martin-Rendon E, Barber RD, Mitrophanous KA, Carter EE, Rohll JB, Kingsman M, Kingsman AJ and Mazarakis ND (2002) Multicistronic lentiviral vector-mediated striatal gene transfer of aromatic L-amino acid decarboxylase, tyrosine hydroxylase, and GTP cyclohydrolase I induces sustained transgene expression, dopamine production, and functional improvement in a rat model of Parkinson's disease. J Neurosci 22:10302-10312.

Baekelandt V, Claeys A, Eggermont K, Lauwers E, Strooper BD, Nuttin B and Debyser Z (2002) Characterization of lentiviral vector-mediated gene transfer in adult mouse brain. Human Gene Ther 13:841-853.

Bahner I, Kearns K, Coutinho S, Leonard EH and Kohn DB (1997) Infection of human marrow stroma by human immunodeficiency virus-1 (HIV-1) is both required and sufficient for HIV-1 induced hematopoietic suppression in vitro: Demonstration by gene modification of primary human stroma. Blood 90:1787-17898.

Bainbridge JWB, Stehens C, Parsley K, Demaison C, Halfyard A, Thrasher AJ and Ali RR (2001) In vivo gene transfer to the mouse eye using an HIV based lentiviral vector; efficient long-term transduction of corneal endothelium and retinal pigment epithelium. Gene Ther 8:1665-1668.

Blaese RM, Culver KW, Miller AD, Carter CS, Fleisher T, Clerici M, Shearer G, Chang L, Chiang Y, Tolstoshev P, Greeblatt JJ, Rosenberg SA, Klein H, Berger M, Mullen CA, Ramsey WJ, Muul L, Morgan RA and Anderson WF (1995) T lymphocyte-directed gene therapy for ADA-SCID: Initial trial results after 4 years. Science 270:475-480.

Blesch A (2004) Lentiviral and MLV based retroviral vectors for ex vivo and gene transfer. Methods 33:164-172.

Blömer U, Naldini L, Kafri T, Trono D, Verma IM and Gage FH (1997) Highly efficient and sustained gene transfer in adult neurons with a lentivirus vector. J Virol 71:6641-6649.

Bonamino M, Serafini M, D’Amico G, Gaipa G, Todisco E, Bernasconi S, Golay J, Biondi A and Introna M (2004) Functional transfer of CD40L gene in human B-cell precursor ALL blasts by second-generation SIN lentivectors. Gene Ther 11:85-93.

Bordignon C, Notarangelo LD, Nobili N, Ferrari G, Casorati G, Panina P, Mazzolari E, Maggioni D, Rossi C, Servida P, Ugazio AG and Mavilio F (1995) Gene Therapy in peripheral blood lymphocytes and bone marrow for ADA immunodeficient patients. Science 270:470-475.

Bukrinsky MI, Sharova N, Dempsey MP, Stanwick TL, Bukrinskaya AG, Haggerty S and Stevenson M (1992) Active nulear import of human immunodeficiency virus type 1 preintegration complexes. Proc Nat Acad Sci USA 89:65806584.

Burns JC, Friedmann T, Driever W, Burrascano M and Yee J-K (1993) Vesicular stomatitis virus g glycoprotein pseudotyped retroviral vectors: Concentration to a very high titer and efficient gene transfer into mammalian and nonmammalian cells. Proc Nat Acad Sci USA 90:8033-8037.

Carlotti F, Bazuine M, Kekarainen T, Seppen J, Pognonec P, Maasen JA and Hoeben RC (2004) Lentiviral vectors efficiently transduce quiescent mature 3T3-L1 adipocytes. Mol Ther 9:209-218.

Case SS, Price MA, Jordan CT, Yu XJ, Wang L, Bauer G, Haas DL, Xu D, Stripecke R, Naldini L, Kohn DB and Crooks GM (1999) Stable transduction of quiescent CD34+CD38human hematopoietic cells by HIV-1-based lentiviral vectors. Proc Nat Acad Sci USA 96:2988-2993.

Cavazzana-Calvo M, Hacein-Bey S, Basile G, Gross F, Yvon E, Nusbaum P, Selz F, Hue C, Certain S, Casanova J-L, Bousso P, Le Deist F and Fischer A (2000) Gene therapy of human severe combined immunodeficiency (SCID)-X1 disease. Science 288:669-672.

Check E (2002a) Gene therapy: A tragic setback. Nature 420:116-118.

Check E (2002b) Regulators split on gene therapy as patient shows signs of cancer. Nature 419:545-546.

Chen S-T, Lida A, Guo L, Friedmann T and Yee J-K (1996) Generation of packaging cell lines for pseudotyped retroviral vectors of the $\mathrm{G}$ protein of vesicular stomatitis virus by using a modified tetracycline inducible system. Proc Nat Acad Sci USA 93:10057-10062.

Chen J, Reeves L, Sanburn N, Croop J, Williams DA and Cornetta K (2001) Packaging cell line DNA contamination of vector supernatants: Implication for laboratory and clinical research. Virology 282:186-197. 
Chinnasamy N, Chinnasamy D, Toso JF, Lapointe R, Candoti F, Morgan RA and Hwu P (2000) Efficient gene transfer to human peripheral blood monocyte-derived dendritic cells using human immunodeficiency virus type 1-based lentiviral vectors. Human Gene Ther 11:1901-1909.

Chong H, Starkey W and Vile RG (1998) A replication-competent retrovirus arising from a split-function packaging cell line was generated by recombination events between the vector, one of the packaging constructs and endogenous retroviral sequences. J Virol 72:2663-2670.

Chu P, Lutzko C, Stewart AK and Dubé ID (1998) Retrovirusmediated gene transfer into hematopoietic stem cells. J Mol Med 76:184-192.

Corbeau P, Kraus G and Wong-Staal F (1996) Efficient gene transfer by a human immunodeficiency virus type 1 (HIV1)-derived vector utilizing a stable HIV packaging cell line. Proc Nat Acad Sci USA 93:14070-14075.

Cornetta K, Morgan RA and Anderson WF (1991) Safety issues related to retroviral-mediated gene transfer in humans. Hum Gene Ther 2:5-14.

Cosset F-L, Takeuchi Y, Battini JL, Weiss RA and Collins MKL (1995) High titer packaging cells producing recombinant retroviruses resistent to human complement. J Virol 69:7430-7436.

Cui Y, Iwakuma T and Chang LJ (1999) Contributions of viral splice sites and cis-regulatory elements to lentivirus vector function. J Virol 73:6171-6176.

Déglon N, Tseng JL, Bensadoun J-C, Zurn AD, Arsenijevic Y, De Almeida LP, Zufferey R, Trono D and Aebischer P (2000) Self-inactivating lentiviral vectors with enhanced transgene expression as potential gene transfer system in Parkinson's disease. Hum Gene Ther 11:179-190.

Delenda C (2004) Lentiviral vectors: Optimisation of packaging, transduction and gene expression. J Gene Med 6:S125S138.

Demaison C, Parsley K, Brouns G, Scherr M, Battmer K, Kinnon C, Grez M and Trasher AJ (2002) High level transduction and gene expression in hematopoietic repopulating cells using a human immunodeficiency virus type 1-based lentiviral vector containing an internal spleen focus forming virus promotor. Human Gene Ther 13:803-813.

Di Domenico C, Villani GRD, Di Napoli D, Reyero EGY, Lombardo A, Naldini L and Di Natale P (2005) Gene therapy for mucoploysaccharidosis type I murine model with lentiviral-IDUA vector. Hum Gene Ther 16:81-90.

Dull T, Zufferey R, Kelly M, Mandel RJ, Nguyen M, Trono D and Naldini L (1998) A third-generation lentivirus vector with a conditional packaging system. J Virol 72:8463-8471.

Dvorin JD, Bell P, Maul GG, Yamashita M, Emerman M and Malim MH (2002) Reassessment of the roles of integrase and the central DNA flap in human immunodeficiency virus type 1 nuclear import. J Virol 76:12087-12096.

Escarpe P, Zayek N, Chin P, Borellini F, Zufferey R, Veres G and Kiermer V (2003). Development of a sensitive assay for detection of replication-competent recombinant lentivirus in large-scale HIV-based vector preparation. Mol Ther 8:332341 .

Farson D, Witt R, McGuinness R, Dull T, Kelly M, Song J, Radeke R, Bukovsky A, Consiglio A and Naldini L (2001) A new-generation stable inducible packaging cell line for lentiviral vectors. Human Gene Ther 12:981-997.
Gallay P, Hope T, Chin D and Trono D (1997) HIV-1 infection of nondividing cells through the recognition of integrase by the importin/karyopherin pathway. Proc Nat Acad Sci USA 94:9825-9830.

Gasmi M, Glynn J, Jin M-J, Jolly DJ, Yee J-K and Chen S-T (1999) Requirements for efficient production and transduction of human immunodeficiency virus type 1-based vectors. J Virol 73:1828-1834.

Hacein-Bey-Abina S, Von Kale C, Schimdt M, McCormack MP, Wulffraat N, Leboulch P, Lim A, Osborne CS, Pawliuk R, Morillon E, Sorenses R, Forster A, Fraser P, Cohen JI, Basile GS, Alexander I, Wintergerst U, Frebourg T, Aurias A, Stoppa-Lyonnet D, Romana S, Radford-Weiss I, Gross F, Valensi F, Delabesse E, Macintyre E, Sigauxn F, Soulier J, Leiva LE, Wissler M, Prinz C, Rabbits TH, Le Deist F, Fischer A and Cavazzana-Calvo M (2003) LMO2associated clonal $\mathrm{T}$ cell proliferation in two patients after gene therapy for SCID-X1. Science 302:415-419.

Han JJ, Mhatre AN, Wareing M, Pettis R, Gao W-Q, Zufferey RN, Trono D and Lalwani AK (1999) Transgene expression in the guinea pig cochlea mediated by lentivirus- derived gene transfer. Human Gene Ther 10:1867-1873.

Hildinger M, Abel KL, Ostertag W and Baum C (1999) Design of 5 ' untranslated sequences in retroviral vectors developed for medical use. J Virol 73:4083-4089.

Hofmann A, Kessler B, Ewerling S, Weppert M, Vogg B, Ludwig H, Stojkovic M, Boelhauve M, Brem G, Wolf E and Pfeifer A (2000) Efficient transgenesis in afrm animals by lentivral vectors. EMBO 4:1054-1058.

Holmes, EC (2001) On the origin and evolution of the human immunodefiency virus (HIV) Biol Rev 76:239-254.

Imren S, Fabry ME, Westerman KA, Pawliuk R, Tang P, Rosten PM, Nagel RL, Leboulch P, Eaves CJ and Humphries RK (2004) High-level- $\beta$-globin expression and preferred intragenic integration after lentiviral transduction of human cord blood stem cells. J Clin Invest 114:953-962.

Ismail SI, Kingsman SM, Kingsman AJ and Uden M (2000) Split-intron retroviral vectors: Enhanced expression with improved safety. J Virol 74:2365-2371.

Iwakuma T, Cui Y and Chang L-J (1999) Self-inactivating lentiviral vectors with U3 and U5 modifications. Virology 261:120-132.

Johnson LG, Olsen JC, Naldini L and Boucher RC (2000) Pseudotyped human lentiviral vector-mediated gene transfer to airway epithelia. Gene Ther 7:568-574.

Kafri T, van Praag H, Ouyang L, Gage FH and Verma IM (1999) A packaging cell line for lentivirus vectors. J Virol 73:576584.

Kearns-Jonker M, Fischer-Lougheed J, Shulkin I, Kleihauer A, Mitsuhashi N, Kohn DB, Weinberg K, d'Apice A, Starnes VA and Cramer DV (2004) Use of lentiviral vectors to induce long-term tolerance to gal+ heart grafts. Transplantation 71:1748-1754.

Kim VN, Mitrophanous K, Kingsman S and Kingsman AJ (1998) Minimal requirement for a lentivirus vector based on human immunodeficiency virus type 1. J Virol 72:811-816.

Klages N, Zufferey R and Trono D (2000) A stable system for the high titer production of multiply attenuated lentiviral vectors. Mol Ther 2:170-176.

Klarmann GJ, Chen X, North TW and Preston BD (2003) Incorporation of uracil into minus strand DNA affects the speci- 
ficity of plus strand synthesis initiation during lentiviral reverse transcription. J Biol Chem 278:7902-7909.

Kok MR, Voutetakis A, Yamano S, Wang J, Cotrim A, Katano H, Bossis L, Chiorini JA, Tran SD, Tak PP and Baum BJ (2004) Immune responses following salivary gland administration of recombinant adeno-associated virus serotype 2 vectors. J Gene Med 7:432-441.

Kostic C, Chiodini F, Salmon P, Wiznerowicz M, Deglon N, Hornfeld D, Trono D, Aebischer P, Schorderet DF, Munier FL and Arsenijevic Y (2003) Activity and analysis of housekeeping promoters using self-inactivating lentiviral vector delivery into the mouse retina. Gene Ther 10:818-821.

Kowolik CM, Yam P, Yu Y and Yee JK (2003) HIV vector production mediated by Rev protein transduction. Mol Ther 8:324-331.

Kraunus J, Schaumann DH, Meyer J, Modlich U, Fehse B, Brandenburg G, von Laer D, Klump H, Schambach A, Bohne J and Baum (2004) Self-inactivating retroviral vectors with improved RNA processing. Gene Ther 11:1568-1578.

Lanciotti E (2001) Microbiologia Clinica. 2nd edition. Casa Editrice Ambrosiana, Itália, $421 \mathrm{pp}$.

Landau NR, Page KA and Littman DR (1991) Pseudotyping with human T-cell leukaemia virus type I broadens the human immunodeficiency virus host range. J Virol 65:162-169.

Lever AM, Strappe PM and Zhao J (2004) Lentiviral vectors. J Biomed Sci 11:439-449.

Logan AC, Haas DL, Kafri T and Kohn DB (2004) Integrated self-inactivating lentiviral vectors produce full-length genomic transcripts competent for encapsidation and integration. J Virol 78:8421-8436.

Lois C, Hong EJ, Pease S, Brown EJ and Baltimore D (2002) Germline transmission and tissue specific expression of transgenes delivered by lentiviral vectors. Science 295:868-872.

Louboutin J-P, Wang L and Wilson JM (2004) Gene transfer into skeletal muscle using novel AAV serotypes. J Gene Med 7:442-451.

Ma Y, Ramezani A, Lewis R, Hawley RG and Thomson JA (2003) High level sustained transgene expression in human embryonic stem cells using lentiviral vectors. Stem Cells 21:111-117.

Manganini M, Serafini M, Bambacioni F, Casati C, Erba E, Follenzi A, Naldini L, Bernasconi S, Gaipa G, Rambaldi A, Biondi A, Golay J and Introna M (2002) A human immunodeficiency virus type 1 pol gene-derived sequence (cPPT/CTS) increases the efficiency of transduction of human nondividing monocytes and $\mathrm{T}$ lymphocytes by lentiviral vectors. Human Gene Ther 13:1793-1807.

Mangeot P-E, Cosset F-L, Colas P and Mikaelian I (2004) A universal transgene silencing method based on RNA interference. Nucleic Acid Res 32:e102.

Manilla P, Rebello T, Afable C, Lu X, Slepushkin V, Humeau LM, Schonely K, Ni Y, Binder GK, Levine BL, Macgegor R-R, June CH and Boro Dropulic (2005) Regulatory considerations for novel gene therapy products: A review of the process leading to the first clinical lentiviral vector. Hum Gene Ther 16:17-25.

Markusic D, Oude-Elferink R, Das AT, Berkhout B and Seppen J (2005) Comparison of single regulated lentiviral vectors with rtTA expression driven by an autoregulatory loop or a constitutive promoter. Nucleic Acids Res 33:e63.
Meirelles LS and Nardi NB (2003) Murine marrow-derived mesenchymal stem cell: Isolation, expansion, and characterization. Brit J Haematol 123:702-711.

Mitta B, Weber CC, Rimann M and Fussenegger M (2004) Design and characterization of self-inactivating human and nonhuman lentiviral expression vectors engineered for streptogramin-adjustable transgene expression. Nucl Ac Res 32:e106.

Miyoshi H, Blömer U, Takahashi M, Gage FH and Verma IM (1998) Development of a self-inactivating lentivirus vector. J Virol 72:8150-8157.

Miyoshi H, Smith KA, Mosier DE, Verma IM and Torbett BE (1999) Transduction of human CD34+ cells that mediate long-term engrafment of NOD/SCID mice by HIV vectors. Science 283:682-686.

Mordelet E, Kissa K, Calvo C-F, Lebastard M, Milon G, Van der Werf S, Vidal C and Charneau P (2002) Brain engraftment of autologous macrophages transduced with a lentiviral flap vector: An approach to complement brain dysfunctions. Gene Ther 9:46-52.

Naldini L (1998) Lentiviruses as gene transfer agents for delivery to non-diving cells. Curr Opin Biotechnol 9:457-463.

Naldini L, Blömer U, Gage FH, Trono D and Verma IM (1996a) Efficient transfer, integration, and sustained long-term expression of the transgene in adult rat brains injected with a lentiviral vector. Proc Nat Acad Sci USA 93:11382-11388.

Naldini L, Blömer U, Gallay P, Ory D, Mulligan R, Gage FH, Verma IM and Trono D (1996b) In vivo gene delivery and stable transduction of nondividing cells by a lentiviral vector. Science 272:263-267.

Novina CD and Sharp PA (2004) The RNAi revolution. Nature 430:161-164.

Ory DS, Neugeboren BA and Mulligan RC (1996) A stable human-derived packaging cell line for production of high titer retrovirus/vesicular stomatitis virus g pseudotypes. Proc Nat Acad Sci USA 93:11400-11406.

Otto E, Jones-Trower A, Vanin EF, Stambaugh K, Mueller SN, Anderson WF and McGarrit GJ (1994) Characterization of a replication-competent retrovirus resulting from recombination of packaging and vector sequences. Human Gene Ther 5:567-575.

Page KA, Landau NR and Littman DR (1990) Construction and use of a human immunodeficiency virus vector for analysis of virus infectivity. Proc Nat Acad Sci USA 64:5270-5276.

Pagès JC and Bru T (2004) Toolbox for retrovectorologists. J Gene Med 6:S67-S82.

Pan D, Gunther R, Duan W, Wendell S, Kaemmerer W, Kafri T, Verma IM and Whitley CB (2002) Biodistribution and toxicity studies of VSVG-pseudotyped lentiviral vector after intravenous administration in mice with the observation of transduction of bone marrow. Mol Ther 6:19-29.

Park F and Kay MA (2001) Modified HIV-1 based lentiviral vectors have an effect on viral transduction efficiency and gene expression in vitro and in vivo. Mol Ther 4:164-173.

Parolin C, Dorfman T, Palù G, Gottlinger H and Sodroski J (1994) Analysis in human immunodeficiency virus type 1 vectors of cis-acting sequences that affect gene transfer into human lymphocytes. J Virol 68:3888-3895.

Pear WS, Nolan GP, Scott ML and Baltimore D (1993) Production of high titer helper-free retroviruses by transient transfection. Proc Nat Acad Sci USA 90:8392-8396. 
Pizzato M, Merten OW, Blair ED and Takeuchi Y (2001) Development of a suspension packaging cell line for production of high titer, serum-resistent murine leukemia virus vectors. Gene Ther 8:737-745.

Poeschla E, Corbeau P and Wong-Staal F (1996) Development of HIV vectors for anti-HIV gene therapy. Proc Nat Acad Sci USA 93:11395-11399.

Price MA, Case SC, Carbonaro DA, Yu X-J, Petersen D, Sabo KM Curran MA, Engel BC, Margarian H, Abkowitz JL, Nolan GP, Kohn DB and Crooks GM (2002) Expression from second-generation feline immunodeficiency virus is impaired in hematopoietic cells. Mol Ther 6:645-652.

Ramezani A, Hawley TS and Hawley RG (2000) Lentiviral vectors for enhanced gene expression in human hematopoietic cells. Mol Ther 2:458-469.

Reiser J (2000) Production and concentration of pseudotyped HIV-1 based gene transfer vectors. Gene Ther 7:910-913.

Reiser J, Harmison G, Stahl SK, Brady RO, Karlson S and Schubert M (1996) Transduction of nondividing cells by using pseudotyped defective high-titer HIV type 1 particles. Proc Nat Acad Sci USA 93:15266-15271.

Reiser J, Lai Z, Zhang X-Y and Brady RO (2000) Development of multigene and regulated lentivirus vectors. J Virol 74:10589-10599.

Rivella S, May C, Chadburn A, Rivière I and Sadelain M (2003) A novel murine model of Cooley anemia and its rescue by lentiviral-mediated human b-globina gene transfer. Blood 101:2932-2939.

Romano G, Micheli P, Pacilio C and Giordano A (2000) Latest developments in gene transfer technology: Achievements, perspectives, and controversies over therapeutic applications. Stem Cells 18:19-39.

Rubinson DA, Dillon CP, Kwiatkowski AV, Sievers C, Yang L, Kopinja J, Zhang M, McManus MT, Gertler FB, Scott ML and Parijs LV (2003) A lentivirus-based system to functionally silence genes in primary mammalian cells, stem cells and transgenic mice by RNA interference. Nat Genet 33:401-406.

Salmon P, Kindler V, Ducrey O, Chapuis B, Zubler RH and Trono D (2000) High-level transgene expression in human hematopoietic progenitors and differentiated blood lineages after transduction with improved lentiviral vectors. Blood 96:3392-3398.

Sastry L, Johnson T, Hobson MJ, Smucker B and Cornetta K (2002) Titering lentiviral vectors:comparison of DNA, RNA and marker expression methods. Gene Ther 9:1155-1162.

Sastry L, Xu Y, Johnson T, Desai K, Rissing D, Marsh J and Cornetta K (2003) Certification assays for HIV-1 based vectors: Frequent passage of gag sequences without evidence of replication-competent viruses. Mol Ther 8:830-839.

Schambach A, Wodrich H, Hildinger M, Bohne J, Kräusslich H-G and Baum C (2000) Context dependence of different modules for posttranscriptional enhancement of gene expression from retroviral vectors. Mol Ther 2:435-445.

Scherr M, Battmer K, Schultheis B, Ganser A and Eder M (2005) Stable RNA interference (RNAi) as an option for anti-bcrabl therapy. Gene Ther 12:12-21.

Schröder ARW, Shinn P, Chen H, Berry C, Ecker JR and Bushman F (2002) HIV-1 integration in the human genome favors active genes and local hotspots. Cell 110:521-529.
Sheridan PL, Bodner M, Lynn A, Phuong TK, DePolo NJ, Vega DJ, O'Dea J, Nguyen K, McCormack JE, Driver DA, Townsend K, Ibañez CE, Sajjadi NC, Greengard JS, Moore MD, Respess J, Chang SMW, Dubensky TW, Jolly DJ and Sauter SL (2000) Generation of retroviral packaging and producer cell lines for large-scale vector production and clinical application:improved safety and high titer. Mol Ther 2:262-2775

Silva EA (2002) O vírus da imunodeficiência felina (FIV) como vetor de transferência gênica para células de linhagem hematopoiética e estroma de medula óssea murina. Dissertação de Mestrado, Universidade Federal do Rio Grande do Sul, Porto Alegre.

Sirven A, Pflumio F, Zennou V, Titeux M, Vainchenker W, Coulombel L, Dubart-Kupperschmitt A and Charneau P (2000) The human immunodeficiency virus type-1 central DNA flap is a crucial determinant for lentiviral vector nuclear import and gene transduction of human hematopoietic stem cells. Blood 96:4103-4110.

Sirven A, Ravet E, Charneau P, Zennou V, Coulombel L, Guétard D, Pflumio F and Dubart-Kupperschmitt (2001) Enhanced transgene expression in cord blood CD34+-derived hematopoietic cells, including developing T cells and NOD/SCID mouse repopulating cells, following TRIP lentiviral vectors. Mol Ther 3:438-448.

Soneoka Y, Cannon PM, Ramsdale EE, Griffiths JC, Romano G, Kingsman SM and Kingsman AJ (1995) A transient threeplasmid expression system for the production of high titer retroviral vectors. Nucl Ac Res 23:628-633.

Stevenson M (2000) HIV nuclear import: What's the flap? Nat Med 5:626-627.

Strang BL, Takeuchi Y, Relander T, Richter J, Bailey R, Sanders DA, Collins MKL and Ikeda Y (2005) Human immunodeficiency virus type 1 vectors with alphavirus envelope glycoproteins produced from stable packaging cells. J Virol 79:1765-1771.

Sui G, Affar EB, Shi Y, Brignone C, Wall NR, Yin P, Donohoe M, Luke MP, Calvo D, Grossman SR and Shi Y (2004) Yin Yang is a negative regulator of $\mathrm{p} 53$. Cell 117:859-872

Sutton RE, Wu HTM, Rigg R, Böhnlein E and Brown PO (1998) Human immunodeficiency virus type 1 vectors efficiently transducer human hematopoietic stem cells. J Virol 72:5781-5788.

Swanstrom R and Wills JW (1997) Retroviral gene expression:synthesis, assembly and processing of viral proteins. In: Varmus HE, Coffin JM and Hughes SH (eds) Retroviruses. Cold Spring Harbour Laboratory Press, New York, pp 263334.

Takahashi M, Miyoshi H, Verma IM and Gage FH (1999) Rescue from photoreceptor degeneration in the rd mouse by human immunodeficiency virus vector-mediated gene transfer. J Virol 73:7812-7816.

Tsugawa T, Kuwashima N, Sato H, Fellows-Mayle WK, Dusak JE, Okada K, Papworth GD, Watkins SC, Gambotto A, Yoshida J, Pollack IF and Okada H (2004) Sequential delivery of interferon-alfa gene and DCs to intracranial gliomas promote an effective antitumor response. Gene Ther 11:1551-1558.

Uchida H, Tanaka T, Sasaki K, Kato K, Dehari H, Ito Y, Kobune M, Miyagishi M, Taira K, Tahara H and Hamada H (2004) Adenovirus-mediated transfer of siRNA against surviving 
induced apoptosis and attenuated tumor cell growth and. Mol Ther 10:162-171.

Van Maele B, Rijck JD, Clercq ED and Debyser Z (2003) Impact of the central polypurine tract on the kinetics of human immunodeficiency virus type 1 vector transduction. J Virol 77:4685-4694.

Vanden Driessche T, Thorrez L, Naldini L, Follenzi A, Moons L, Berneman Z, Collen D and Chuah MKL (2002) Lentiviral vectors containing the human immunodeficiency vírus type-1 central polypurine tract can efficiently transduce nondiving hepatocytes and antigen-presenting cells. Blood 100:813-822.

Verhoef K, Marzio G, Hillen W, Bujard H and Berkhout B (2001) Strict control of human immunodeficiency virus type 1 replication by a genetic switch: Tet for Tat. J Virol 75:979-987.

Vodicka MA, Koepp DM, Silver PA and Emerman M (1998) HIV-1 Vpr interacts with the nuclear transport pathway to promote macrophage infection. Genes Development 12:175-185.

Wang X, Appukuttan B, Ott S, Patel R, Irvine J, Song J, Park J-HC, Smith R and Stout JT (2000) Efficient and sustained transgene expression in human corneal cells mediated by a lentiviral vector. Gene Ther 7:196-200.

Wollmann G, Tattersall P and Pol NVD (2005) Targeting human glioblastoma cells: Comparison of nine viruses with oncolytic potential. J Virol 79:6005-6022.

Wu X, Wakefield JK, Liu H, Xiao H, Kralovics R, Prchal JT and Kappes JC (2000) Development of a novel trans-lentiviral vector that affords predictable safety. Mol Ther 2:47-55.

Wu X, Li Y, Crise B and Burgess SM (2003) Transcription start regions in the human genome are favored targets for MLV integration. Science 300:1749-1751.

Xu K, Ma H, McCown TJ, Verma IM and Kafri T (2001) Generation of a stable cell line producing high-titer self-inactivating lentiviral vectors. Mol Ther 3:97-104.
Yam PY, Li S, Wu J, Hu J, Zaia JA and Yee J-K (2002) Design of HIV vectors for efficient gene delivery into human hematopoietic cells. Mol Ther 5:479-484.

Yang J, Mani SA, Donaher JL, Ramaswamy S, Itzykson RA, Come C, Savagner P, Gitelman I, Richardson A and Weinberg RA (2004) Twist, a master regulator of morphogenesis, plays an essential role in tumor metastasis. Cell 117:927939.

Yee J-K, Miyanohara A, LaPorte P, Bouic K, Burns JC and Friedman T (1994) A general method for the generation of hightiter, pantropic retroviral vactors:highly efficient infection of primary hepatocytes. Proc Nat Acad Sci USA 91:95649568.

Zaiss A-K, Son S and Chang L-J (2002) RNA 3' readthrough of oncoretrovirus and lentivirus: Implications for vector safety and efficacy. J Virol 76:7209-7219.

Zhang X-Y, La Russa VF, Bao L, Kolls J, Schwarzenberger P and Reiser J (2002) Lentiviral vectors for sustained transgene expression in human bone marrow-derived stromal cells. Mol Ther 5:555-565.

Zhu Y, Feuer G, Day SL, Wrzesinski S and Planelles V (2001) Multigene lentiviral vectors based on differential splicing and translational control. Mol Ther 4:375-382.

Zufferey R, Nagy D, Mandel RJ, Naldini L and Trono D (1997) Multiply attenuated lentiviral vector achieves efficient delivery. Nat Biotechnol 15:871-875.

Zufferey R, Dull T, Mandel RJ, Bukovsky A, Quiroz D, Naldini L and Trono D (1998) Self-inactivating lentivirus vector for safe and efficient gene delivery. J Virol 72:9873-9880.

\section{Eletronic Resources}

The URL for data presented here is as follows:

Gene Therapy Clinical Trials Worldwide, http://82.182.180.141/ trials/FMPro.

Lee YJ, Belgian Biosafety Server, http://www.biosafety.be/GT/ Regulatory/RapportEN27_06_2001.pdf. Associate Editor: Carlos F.M. Menck 